\title{
"Seniors emergency departments" yield health improvements, advocates say
}

$\mathrm{P}$ roponents call them a veritable redesign of emergency care for seniors. At least a dozen of the "seniors emergency departments" have been opened in the United States and early indicators are that they yield fewer harmful drug interactions, higher patient satisfaction and decreased hospital readmission rates.

The seniors emergency departments or seniors emergency centres, as some call them, typically feature highly trained geriatric staff offering specialized care, while arguably achieving better health outcomes by providing such amenities as softer ambient lighting, nonslip flooring, walls equipped with handrails, oversized clocks, hearing amplifiers and other technologies designed to enhance communication with patients.

The first such geriatric emergency room was introduced by Trinity Health Systems, a network of nonprofit community hospitals, in 2008 at Holy Cross Hospital in Silver Spring, Maryland. The network plans to open an additional 19 centres by 2013 .

The care offered typically involves diagnosis and treatment by multidisciplinary geriatric teams that include physicians, nurses, occupational therapists and social workers.

The approach allows for better assessment of patients who present with vague symptoms overlying often complex medical problems and is essentially "redesigning" care for seniors, says Dr. Mark Rosenberg, emergency medicine chairman for St. Joseph's Regional Medical Center in Paterson, New Jersey.

Rosenberg asserts that early successes at St. Joseph's prompted others to follow suit and that families are now actively seeking care in such facilities, which offer more comprehensive combination therapies. "There are many hospitals here and children in particular, some in their 50s, are insisting their parents are going to St. Joseph's for our senior expertise,"

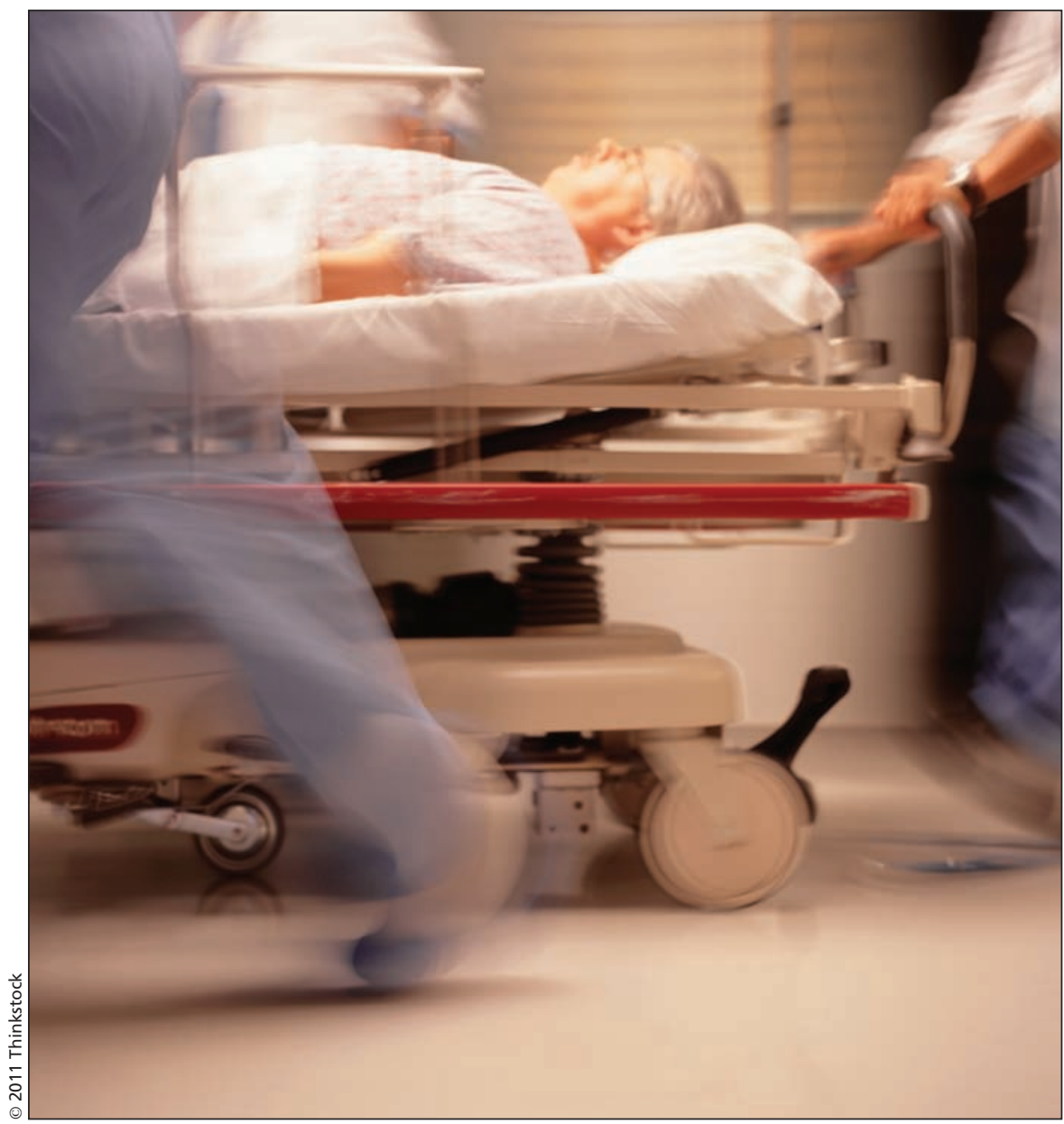

The cost of treating senior citizens in the United States will reach US\$54 billion by 2020 , according to the US Centers for Disease Control and Prevention.

Rosenberg says. "We see about 130000 patients visit a year and approximately 39000 are visits through our senior ER [emergency room]."

Such facilities increase staff awareness about the qualititative difference in care that should be provided to seniors, says Dr. James Del Vecchio, medical director of the Holy Cross emergency department. "It's very eyeopening for physicians to nursing staff to see the difference of care for these senior patients."

Hospitals that cannot afford designated seniors emergency departments could nevertheless improve their geri- atric services by adopting a multidisciplinary approach, Del Vecchio says. "There is absolutely no reason that other hospitals can't incorporate the same processes or comfort measures and same screening tools that we have done on a smaller scale."

The therapeutic benefits are enormous relative to the costs, he adds. "The physical cost of renovating (Holy Cross) was about US\$150 000 but that's relatively small. You have to look at the return of investment and if you're having improved patient outcome, improved patient satisfaction and less unnecessary returns to the hospitals, 
those increased costs can be recouped fairly quickly."

Rosenburg says a lower incidence of injuries such as falls within senior emergency departments reduces the need for treatment and ultimately alleviates costs. "We are preventing revisits to the emergency department and are preventing functional decline, therefore better health care and less revisits is saving everybody."

According to the US Centers for Disease Control and Prevention projections, the cost of treating injuries among seniors will reach a staggering US\$54 billion by 2020 .

Seniors emergency departments haven't yet surfaced in Canada but there is increasing emphasis being placed on more coordinated care, says Pamela Fralick, president of the Canadian Healthcare Association.

There are increased investments being made in such things as wellness clinics that offer preventive, educational and rehabilitation services, Fralick says. "There are 16-week programs that help educate and inform older adults as to how they can remain independent and stay at home longer. Nowadays, seniors are becoming increasingly skilled with technology."

If there is a Canadian parallel to the seniors emergency departments, it may be the Geriatric Emergency Management Program in Ontario, which links senior emergency department visits to supportive health care services.

But Dr. Sharon Straus, division director of geriatric medicine at the University of Toronto in Ontario says there are several initiatives being developed across Canada to address the challenges of providing geriatric care, such as virtual wards, or triage teams that aim to coordinate and provide care outside of hospital settings.

Such an approach includes "intense case management and patients are seen within their homes in 24 hours by a multidisciplinary team. They are not specifically targeted to older patients, but a large proportion of their patients are older," Straus says. - Caroline George, Ottawa, Ont.

CMAJ 2011. DOI:10.1503/cmaj.109-3868
Editor's note: Fifteenth of a series on end-of-life care

Part I: Preparing for the inevitable (www.cmaj.ca/lookup/doi/10.1503/cmaj.109-3704)

Part II: Advance directives: Obstacles in preparing for the worst (www.cmaj.ca/lookup/doi/10.1503/cmaj.109-3743)

Part III: End-of-life planning framework calls for fewer checklists, more conversation (www.cmaj.ca/lookup/doi/10.1503/cmaj.109-3746)

Part IV: Tools help patients tackle tough choices for end-of-life care (www.cmaj.ca/lookup/doi/10.1503/cmaj.109-3750)

Part V: National home care standards urged (www.cmaj.ca/lookup/doi/10.1503/cmaj.109-3731)

Part VI: Access to palliative care varies widely across Canada (www.cmaj.ca/lookup/doi/10.1503/cmaj.109-3763)

Part VII: Framework urges physicians to proceed with caution on palliative sedation (www.cmaj.ca/lookup/doi/10.1503/cmaj.109-3766)

Part VIII: Pocket-sized help for people with dementia (www.cmaj.ca/lookup/doi/10.1503/cmaj.109-3705)

Part IX: Grief therapy for those left behind (www.cmaj.ca/lookup/doi/10.1503/cmaj.109-3793)

Part X: Providing hospice in the womb (www.cmaj.ca/lookup/doi/10.1503/cmaj.109-3776)

Part XI: Providing palliative care to the homeless (www.cmaj.ca/lookup/doi/10.1503/cmaj.109-3756)

Part XII: England examines funding options for end-of-life care (www.cmaj.ca/lookup/doi/10.1503/cmaj.109-3849)

Part XIII: Paramedic program reducing emergency room congestion (www.cmaj.ca/lookup/doi/10.1503/cmaj.109-3897)

Part XIV: Legal ambiguities surround authority to make end-of-life decisions (www.cmaj.ca/lookup/doi/10.1503/cmaj.109-3910) 